\title{
Таня Попович
}

DOI: $10.31168 / 91674-576-4.24$

Белградский университет, Сербия

tanja.popovic19@gmail.com

\section{- $\quad$ Постмодернистские комментарии \\ 122 «Хазарский словарь» М. Павича}

В докладе рассматриваются соотношения между текстами жития Константина Философа - св. Кирилла и романа М. Павича «Хазарский словарь». В раскрытие темы указывается на интертекстуальность (гипертекст / гипотекст) и метатекстуальность (автореференциальные комментарии), философию вымысла, принцип дополнительности и возможные миры как на области соприкосновения указанных текстов. Стирание границ между фикциональным и фактуальным началами порождает особенный вид литературного дискурса, причем семантические и формообразующие функции текста никогда четко не разграничены между собою.

Ключевые слова: «Хазарский словарь», Константин Философ, Мефодий, метатекстуальность, возможные миры, фикциональность, фактуальность

Первый роман Милорада Павича «Хазарский словарь» (1984) с самого начала привлёк к себе большой интерес и публики, и критики. До его выхода Павич был известен как профессор сербской литературы XVIII в., переводчик Байрона и Пушкина, а также как автор нескольких изложений историй сербской литературы от XVI до XIX вв. «Хазарский словарь» далеко не первое его «фикциональное» произведение. До начала 80-х гг. сербский писатель напечатал ряд повестей, в которых фикция соединялась с документальностью или с фактуальностью. И «Хазарский словарь» ведет своеобразный диалог между наукой и худо- 
жеством, связывая в себе исторические исследования с выдуманной реальностью. Это действительно словарь, в центре которого статьи, посвященные обсуждению главного вопроса всего романа, - хазарской полемики конца IX в., когда хазарскому кагану приснился сон, который он расценил в качестве знамения, что его народу необходимо принять новую религию. Тогда он послал за представителями трех великих религий средиземноморского мира: за христианским священником, а именно - за Константином Философом, за исламским проповедником и раввином. Таким образом, одно из событий «Жития святого Кирилла», хазарское миссионерство, в романе Павича стало основой дальнейшего развёртывания существенных тем и идей произведения, о фатуме каждого «малого народа, чью судьбу определяет борьба высших сил». «Малые народы, такие как мы, сербы, - писал Павич, - всегда под угрозой чуждых ему идеологий» [Šomlo 1990].

Полемика между противопоставленными идеологиями и культурное влияние носителя каждой из них, или, по словам Э. Саида, «культурная оккупация» молодых народов и племён [Саид 2016], в фикции Павича получили не только нарративную обработку, но и своеобразное философское и филологическое толкование.

Взаимоотношения между текстами «Хазарского словаря» и «Жития св. Кирилла» можно определить как отношение между гипер- и гипотекстами и, одновременно, как метатекстуальность. Более того, «статьи» в словаре под заголовками «Кирилл (Константин Солунский)» и «Мефодий Солунский» представляют собой своеобразное смешение научного дискурса с агиографическим хронотопом и автореференциальными комментариями повествователя. Вадим Руднев заметил, что «Хазарский словарь» построен как гипертекст, то есть в нем достаточно разработанная система отсылок, причем в предисловии автор указывает, 
что читать словарь можно как угодно»; а после добавляет, что роман Павича «философски чрезвычайно насыщенный текст, один из самых философских романов XX в., поэтому стоит сделать попытку отыскать основные нити его тончайшей художественной идеологии, ибо философия «Хазарского словаря» дана не в прямых сентенциях, а растворена в художественной ткани романа» [Руднев 2017: 784-788].

В сравнительном анализе текстов жития и романа наше внимание сосредоточим на нескольких существенных вопросах, которые могут объяснить природу логической семантики, как гипертекста, так и гипотекста. В общем, роман переносит важнейшие события из биографий славянских апостолов и приводит основные исторические факты и имена личностей, упомянутых в их агиографиях: иконоборчество, патриарха Фотия и его библиотеку, византийского царя Михаила III, хазарскую и моравскую миссии, «вычерчивание первых писмён славянской азбуки» [Павич 2018: 77], споры Константина и Мефодия с триязычниками в Венеции, их путь в Рим и «отпевание славянской литургии». Кроме того, в конце «статьи» о Константине Философе автор приводит точную, приблизительную и мнимую библиографии научных трудов и источников, посвященных «кирилло-мефодиевскому вопросу». Таким образом, цитатность у Павича реализована симулякром, точнее как «подобие без подлинника» [Эпштейн 2000: 5]. Исторические факты и события, а также и анахронизмы, которые повторяются и в гипотекстах, и в гипертексте, сохранили и преумножили смысл подлинника. Более того, автор пользуется «принципом дополнительности» [Руднев 2017; Эпштейн 2000], с помощью которого нарративная и означающая функция текста соединена с функцией комментария. В таком творческом приеме или художественном поведении легко можно узнать черты постмодернизма. Интертекстуальность и эклектика пави- 
чевского романа на семантическом уровне подходит к пониманию возможных миров [Doležel 2008], а философия вымысла, как одна из существенных характеристик литератур и постмодернизма, и Средневековья, в «Хазарском словаре» проявляется в онирической реальности, т.е. воспроизведении снов Константина Философа, хазарского кагана и хазарской принцессы Ахер. В каждом из этих снов герой поставлен перед выбором будущего, личной судьбы, причем перед ним вырастают возможные миры.

О сходстве «Хазарского словаря» и жития св. Кирилла возможно говорить и на уровне поэтики. И. Шпадиер в своем исследовании о «несходных подобиях» между средневековым и современным искусствами подчеркнула их несколько общих черт: проекцию непредсказуемых возможностей нового воображения, тяготение к стилизации и абстрагированию, а также и к определенному схематизму, стремление к тотальности и всеохватности, т.е. к достижению полноты существа [Шпадиер 2018]. В этом смысле, можно добавить, что «тело текста» постоянно трансформируется. Как писал Ю.М. Лотман, «сложно устроенный текст, распадающийся на иерархию «текстов в текстах»"» образует новую семантику, созданную на «сложном переплетении текстов» [Лотман 1981]. «Текст в тексте»- существенный формообразующий фактор и «Хазарского словаря», и жития Константина и Мефодия. Способность языка естественным образом объединяется в феномене литературы, одновременно становясь орудием воздействия на реальность, как внешнюю (бытовую), так и внутреннюю (фикциональную). Стирание границ между фикциональным и фактуальным началами в «Хазарском словаре» М. Павича, ровно как и в житиях солунских братьев и апостолов, порождает не только игру с реальностью, но и творит своеобразную философию истории литературы. Живой текст сопротивляется мертвой реальности. 


\section{Литература}

Doležel 2008 - Doležel L. Heterekosmika. Fikcija i mogući svetovi. Prev. S. Kalinić. Beograd: Sl. Glasnik, 2008.

Лотман 1981 - Лотман Ю. М. Текст в тексте // Учен. зап. Тартуского ун-та. Вып. 567. 1981.

Павич 2018 - Павич М. Хазарский словарь: роман лексикон в 100000 слов. Пер. с серб. Л. Савельева. СПб.: Азбука. Азбука-Аттикус, 2018.

Руднев 2017 - Руднев В. П. Энциклопедический словарь культуры XX века. изд. 2, исп. и доп. СПб.: Азбука, 2017.

Саид 2016 - Саид Э.В. Ориентализм. Западные концепции Востока. изд. 2, исп. и доп. Пер. с англ. и послесловие А.В.Говорунова. СПб.: Русский Міръ, 2016.

Житије Ћирилово 1964 - Житије Ћирилово. Пред. О. Недељковић // Ћирло и Методије. Београд: СКЗ, 1964.

Šomlo 1990 - Šomlo, A. Hazari, ili obnova vizantijskog romana: Razgovori sa Miloradom Pavićem. Beograd: BIGZ, „Narodna knjiga“, 1990.

Шnaдиер 2018 - Шпадиер И. «Несходные подобия»: Средневековье и современное искусство // Текст и традиция. СПб.: Росток. Вып. 6. 2018. С. 77-93.

Эпштейн 2000 - Эпштейн М. Постмодерн в России. Литература и теория. М.: Издание Р. Элинина, 2000.

\section{Tanja Popovic}

University of Belgrade, Serbia

tanja.popovic19@gmail.com

\section{Milorad Pavic's Khazar Dictionary as a Postmodern Comment on the Hagiography of Saints Cyril and Methodius}

The aim of this paper is to investigate the relationship between the texts of the Hagiography of Saint Cyril (Konstantin Philosopher) and the M. Pavich's novel "Khazar Dictionary". The focuses of this research are intertextual- 
ity (hypertext / hypothesis) and metatextuality (auto-referential comments), the philosophy of fiction, the principle of complementarity and possible worlds. Erasing the boundaries between fiction and faction create a special kind of literary discourse, new semantic and formative functions of the text.

Key words: Khazar Dictionary, Hagiography of Saints Cyril and Methodius, Saints Cyril Hagiography, intertextuality, metatextuality, possible worlds, fiction, faction

\section{Анатолий Турилов}

DOI: $10.31168 / 91674-576-4.25$

Институт славяноведения РАН, Россия

aaturilov@gmail.com

\section{К истории «Двухсполовинного» южнославянского}

\section{влияния - культурные связи восточных}

и южных славян в конце XV - середине XVI в.

и их региональные особенности

Доклад посвящен истории культурных (в основном литературных) связей восточных славян с южными в конце XV - середине XVI в. Сопоставляются варианты этих связей для Московского государства с одной стороны и Великого княжества Литовского и Польши с другой.

Ключевые слова: культурные связи, восточнославянские регионь, Молдавия, Афон

Использование в заглавии несколько экстравагантного термина, вызвано ситуацией, сложившейся в историко-филологической науке (по большей части в филологической и даже лингвистической). Рассматриваемый ниже этап культурных связей между восточными и южными славянами был выделен (первоначально в рамках конца XV - первой четверти 